\title{
PERENCANAAN SYARIAH
}

\author{
Muslim Kamil
}

UIN Syarif Hidayatullah Jakarta

\begin{abstract}
$A B S T R A C T$
Any individual or any organization definitely requires planning in a variety of activities. Good planning is not based on sharia, or Islamic-based (conventional) basically has a lot in common, in addition to also have many differences. In this article the author intends to explain the concept - the basic concept of sharia perenaaan well as its association with the concept of conventional planning. Thing - the most important thing in this article is a discussion about the basic concepts, principles, vision, mission, the laws, the feasibility and planning stages in sharia Planning sharia is essentially the same as planning in general, the difference principle is the 'value - value' that surrounded him. Because it takes a lot of socialization and continuing on the planning concept of sharia.
\end{abstract}

Keywords : Individual, Organization, Planning, Sharia

\section{PENDAHULUAN}

Setiap individu dan organisasi dalam konteks dan lingkup apapun pasti memerlukan perencanaan (planning). Tidak hanya terbatas pada orang-orang atau organisasi besar saja,orang-orang atau organisasi kecil juga harus memiliki perencanaan yang jelas.Kenyataan ini semakin tidak bisa dipungkiri dalam situasi dengan permasalahan yang serba kompleks seperti saat ini. Individu atau organisasi manapun yang tidak disipilin dalam menerapkan manajemen, cepat atau lambat pastiakan mengalami kegagalan dalam aktifitasnya. Demikian itu adalah sudah menjadi semacam "hukum" tidak tertulis dalam "dunia" manajemen secara umum.

Sistem perencanaan yang diterapkan oleh masing-masing pribadi atau organisasi perusahaan, dalam beberapa hal bisa saja berbeda satu sama lain. Tetapi secara prinsip tentu memiliki persamaan, hal ini dikarenakan sifat universalitas prinsip-prinsip perencanaan. Perbedaan yang dimaksud di atas adalah perbedaan yang dipengaruhi oleh kondisi internal dan eksternal subyek yang bersangkutan. Misalnya saja, dalam hal jenis organisai yang memiliki perencanaan. Dalam hal ini tidak bisa disamakan, sistem perencanaan pada instansi pemerintahan dengan perusahaan, atau perencanaan yang dimiliki sebuah keluarga dengan sebuah kelompok masyarakat.

Saat ini, kajian dan praktek 'ekonomi syariah' mengalami perkembangan yang sangat cepat. Sebagai bagian dari bidang ilmu ekonomi atau manajemen syariah, kajian tentang ‘perencanaan syariah' juga mengalami perkembangan yang sangat cepat bersamaan dengan ekonomi syariah. Maraknya kajian dan praktek bank syariah, bisnis syariah, asuransi syariah dan belakangan 'perencanaan keuangan syariah' adalah sedikit dari sekian banyak bukti perkembangan ekonomi syariah, termasuk dalam hal ini adalah perencanaan syariah. 
Seperti konsep perencanaan pada umumnya atau 'perencanaan konvensional', dalam 'perencanaan syariah' juga terdapat aturan-aturan umum tentang perencanaan.Tetapi jika dicermati, terdapat beberapa hal perbedaan yang prinsip disamping adanya "kesamaankesamaan" seperti dijelaskan di atas.Hal ini bisa dimaklumi karena konsep perencanaan syariah tentu merupakan konsep perencanaan yang merujuk kepada nilai-nilai agama atau syariah islam.

Berdasarkan dengan semua penjelasan di atas, maka dirasa perlu untuk melakukan penulisan, yang mungkin setidaknya sebagai penguatan untuk penulisan-penulisan sebelumnya tentang ini.Tentang konsep perencanaan syariahsecara umum. Oleh karenanya tulisan ini berjudul : "Perencanaan Syariah". Diharapkan tulisan ini bisa dimanfaatkan tidak saja oleh organisasi bisnis atau perusahaan dan organisasi pemerintahan saja, tetapi juga oleh individu dan organisasi lainnya yang memerlukan kejelasan tentang perencanaan syariah.

\section{METODE PENULISAN (JENIS ARTIKEL)}

Penelitian ini berjenis 'konseptual', yaitu artikel yang pada dasarnya memaparkan secara ilmiah konsep tertentu tentang suatu hal, yang secara substantif relatif mendalam. Dalam konteks ini, penulis hanya mendeskripsikan dan mengelaborasikan beberapa konsep pemikiran dari beberapa referensi.

\section{HASIL DAN PEMBAHASAN}

\section{a. Konsep Dasar Perencanaan Syariah}

Perencanaan atau planning adalah kegiatan awal dalam sebuah pekerjaan dalam bentuk memikirkan hal-hal yang terkait pekerjaan itu agar mendapatkan hasil yang optimal (Didin,Hendri,2007). Perencanaan adalah pemilihan sekumpulan kegiatan dan pemutusan selanjutnya apa yang harus dilakukan, kapan, bagaimana, dan oleh siapa (Hani Handoko,1994). Sedangkan menurut Robbins dan Mary (1999), perencanaan adalah suatu proses yang melibatkan penentuan sasaran atau tujuan organisasi, menyusun strategi menyeluruh untuk mencapai sasaran yang ditetapkan, dan mengembangkan hierarki rencana secara menyeluruh untuk mengintegrasikan dan mengkorrdinasikan kegiatan.

Perencanaan syariah adalah amal atau pekerjaan dalam suatu pekerjaan tertentu, yaitu mempersiapkan semua hal yang diperlukan dari awal sampai dengan akhir pekerjaan, yang niat atau motivasi dan caranya sesuai dengan 'nilai-nilai syariah islam'.

Perencanaan, baik yang konvensional atau syariah juga merupakan sesuatu yang pasti diperlukan adanya, keharusan dan bahkan kebutuhan. Hal ini karena karena secara umum semua hal memerlukan perencanaan. Dalam sebuah hadistyang diriwayatkan Ibnu Mubarok, Rasulullah Saw. Menjelaskan tentang pentingnya suatu perencanaan : 


$$
\text { (إذا أردت أن تفعل أمر ا فتدبر عاقتنه فإن كان خير افامض و إن كان شر افانته) رواه ابن المبارك }
$$

Jika engkau ingin mengerjakan sesuatu pekerjaan maka pikirkanlah akibatnya, jika perbuatan itu baik, ambillah dan jikea perbuatan itu jelek, maka tinggalkanlab (HR Ibnu Mubarak).

Hadist tersebut menjelaskan penting adanya suatu perencanaan dalam melakukan sebuah pekerjaan, sehingga dapat diperhatikan semua hal terkait pekerjaan atau perbuatan yang akan dilakuakn, termasuk akibat baik dan buruknya. Dengan adanya perencanaan, maka insya Allah siapapun akan terhindar dari sikap ragu-ragu untuk melakukan sesuatu. Hal ini penting untuk diperhatikan karena melakukan sesuatu dengan keraguan adalah hal yang tidak produktif. Maka Rasullah Saw mengingatkan umat islam agar meninggalkan keraguan, seperti dalam terjemahan hadist berikut ini :

“.........Tinggalkanlah perkara yang meragukannu menuju perkara yang tidak meragukanmu." (HR. Tirmidzi)

Dalam melakukan perencanaan, ada empat hal yang disangat diperlukan atau harus ada. Pertama, hasil yang ingn dicapai.Hal ini misalnya sesuatu tujuan yang diharapkan atau ingin dicapai dalam melakukan sebuah kegiatan. Kedua, orang yang akan melakukan.Tanpa memastikan siapa yang akan menjalankan sebuah kegiatan maka suatu kegiatan tidak kan berjalan dengan baik. Ketiga, waktu dan skala prioritas.Ini terkait dengan penyesuaian kegiatan, waktu yang tersedia, dan pencapaian yang diinginkan. Keempat, dana. Harus dialokasikan atau dianggarkan dengan baik berapakah biaya yang dihabiskan untuk melakukan sebuah kegiatan.

Perencanaan konvensional (non syariah) jelas-jelas telah dan akan tetap memberikan manfaat yang besar bagi individu atau organisasi. Banyak konsep-konsep perencanaan konvensional yang telah disampaikan oleh para pakar pada zamannya. Konsep-konsep tersebut bisa dikatakan sebagian besar sesuai dengan syariah meskipun sebagian besarnya juga tidak sesuai.

Berbeda dengan perencanaan syariah yang menjadikan syariah islam sebagai 'panduan utama' dalam melakukan perencanaan, tidak demikian halnya dengan perencanaan konvensional. Sistem perencanaan inihanya menjadikan referensi-referensi umum (duniawi) saja sebagai 'panduan utamanya'. Perencanaan syariah 'sangat pasti dan jelas' memiliki 'prinsip' dan 'prioritas' dalam hal program dan kegiatan. Karena "timbangan” berbagai hal kepentingan dalam perencanaan syariah 'sangat akurat', yaitu 'aturan-aturan syariah dan tujuan-tujuannya. Sedangkan dalam perencanaan konvensional, sampai saat ini, prinsip dan prioritas serta alasannya (timbangannya) masih selalu menjadi masalah yang sulit diatasi, terlebih ketika banyaknya kepentingan tertentu yang kurang terkait atau tidak sama sekali dengan visi dan misi organisasi. Wajar, jika perencanaan konvensional (non syariah) tidak 
menjadikan agama (islam) sebagai ideologi atau filosofi subtansial. Hal ini dikarenakan ilmu induknya, yaitu ilmu manajemen dan ilmu ekonomi konvensional juga demikian. Keilmuan ini memisahkan antara filosofis agama dengan teori-teori keilmuannya(sekuler).

\section{b. Prinsip - Prinsip Perencanaan Syariah}

Setiap perencanaan dikatakan baik kalau menerapkan kiat-kiat atau 'prinsip-prinsip prencanaan syariah', yaitu terdapat lima prinsip (Didin,Hendri,2003). Prinsip- prinsip tersebut, yaitu, Pertama, didasarkan pada sebuah 'keyakinan' bahwa apa yang dilakukan adalah 'baik'. Standar baik dalam agama Islam adalah yang sesuai dengan ajaran islam. Kita tidak boleh melakukan sebuah perencanaan untuk melakukan sebuah usaha yang dilarang dalam islam. Walaupun usaha itu menguntungkan dari segi materi, seperti proyek-proyek perzinaan, lokalisasi judi, atau prostitusi, tetapi keuntungan itu akan menghilangkan keberkahan serta mengundang bencana. Secara konvensional, perencanaan yang dibuat tidak memperhatikan prinsip ini. Karena dalam sistem konvensional yang terpenting adalah adanya perencanaan. Kedua, dipastikan bahwa yang dilakukan memiliki banyak manfaat. Manfaat ini bukan sekedar untuk 'orang yang melakukan perencanaan', tetapi juga untuk oranglain. Jika merencanakan sesuatu sekadar untuk kepentingan pribadi, maka usaha itu tidak akan bertahan lama. Oleh karena itu, perlu diperhatikan manfaat yang relatif lama. Manfaat utama dalam sistem konvensional adalah kesenangan pihak tertentu saja. Ketiga, berkaitan dengan ilmu pengetahuan yang berkaitan dengan apa yang akan dilakukan. Sebagian besar teori ilmu yang digunakan dalam perencanaan konvensional pun tentu sama saja dengan perencanaan syariah. Untuk merencanakan bisnis, maka seorang pengusaha harus banyak mendengar dan membaca agar dapat mempertanggungjawbkan segala hal yang dilakukannya.Sesuatu yang ilmiah bukan berarti hal yang besar, tetapi yang kecil pun dapat ilmiah. Sesuatu yang ilmiah bukanlah terletak pada kerumitannya, melainkan terletak pada sesuatu yang bias dipertanggungjawabkan, bukan sebuah khayalan. Pada sisi ini mungkin bisa dikatakan ada perbedaan besar. Karena disadari atau tidak oleh pihak yang menyusun perencanaaan konvensional, perencanaan yang dibuat cenderung terkesan "rumit". Keempat, dilakukan studi banding (benchmark). Benchmark adalah melakukan studi terhadap praktik terbaik dari perusahaan sejenisyang sukses menjalankan bisnisnya. Kita perlu melihat pengalaman oranglain, mengapa mereka sukses ?apa yang mereka lakukan? Bagaimana mereka melakukan sebuah perencanaan ? Hal ini pun dilakukan secara umum dilakukan dengan baik dalm sistem konvensional.Kelima, dipikirkan prosesnya. Proses seperti apa yang akan dilakukan ? Apakah proses itu tetap? Seperti apa hasil (output) dari proses yang direncanakan?Fase ini yang kurang diperhatikan dalam sistem perencanaan konvensional. Sistem konvensional cenderung lebih mengedepankan tujuan dan target walau tidak diikuti langsung dengan pilihan proses yang benar. 
Perencanaan konvensional (non syariah) jelas-jelas telah dan akan tetap memberikan manfaat yang besar bagi siapapun dalam berbagai lingkup kehidupan. Banyak konsep-konsep perencanaan konvensional yang telah disampaikan oleh para pakar pada zamannya.Konsepkonsep tersebut bisa dikatakan sebagian besar sesuai dengan syariah.Meskipun sebagian besarnya juga tidak sesuai.

\section{c. Visi, Misi, dan Perencanaan}

Perencanaan yang baik pasti terdapat visi dan misi yang jelas di dalamnya. Visi adalah tujuan umum yang diinginkan terwujud di masa yang akan datang atau di masa depan. Visi merupakan pandangan, "gambaran" harapan, impian (dream), atau cita - cita.Tentu yang dimaksud dalam hal ini adalah bukan 'impian kosong' atau impian yang tidak didasari oleh kemauan atau komitmen yang kuat dan kemampuan yang realistis untuk mencapainya. Perencanaan pada hakikatnya lebih terfokus pada visi, misi, dan tujuan (www.slideshare.net,2014). Napoleon mengatakan, "Tiada seorangpun dapat memimpin suatu masyarakat tanpa memberikan kejelasan mengenai masa depan mereka, karena seorang pemimpin, sesungguhnya tak lain dari seorang penjual harapan" (Thariq, Faisal, 2006).

Penulis berpendapat, visi adalah "roh" perencanaan. Sebagai perumpamaan bahwa secara umum kehidupan manusia hanya akan terjadi kalau terdapat roh (jiwa atau hati) didalam jasadnya, maka demikian juga halnya antara visi dengan perencanaan. Masih dalam perumpamaan tersebut, untuk memiliki kehidupan yang "baik" maka harus juga memiliki roh yang baik atau sehat. Maka bisa dibayangkan bagaimana jadinya kalau seseorang atau organisasi memiliki perencanaan dengan visi yang tidak jelas atau bahkan tanpa visi sama sekali. Suatu perencanaan yang didalamnya terdapat visi yang jelas dan kuat adalah perencanaan yang bermutu dan bisa dipertanggungjawabkan.Bermutu karena secara strategis dan operasional tujuannya jelas dan dapat dilakukan secara sistemik atau satu kesatuan dari unsur - unsur yang terkait dengan pelaksanaan perencanaan tersebut. Memiliki bobot karena muatan nilai - nilai idealisme kebaikan dan cakupannya.

Dalam konsep perencanaan syariah, visi dan misi harus sesuai dengan prinsipprinsip ajaran agama atau syariah islam. Seperti misalnya prinsip 'rahmatan lil 'alamiin' atau rahmat untuk seluruh kehidupan di alam, adalah visi peran setiap muslim. Maka seorang muslim atau seorang manajer harus memiliki visi perencanaan atau program-program yang tidak keluar atau bertentangan dari prinsip tersebut. Bagi ndividu atau organisasiapapun, visi dalam syariah islam pada dasarnya adalah sesuatu yang bersifat sesuai dengan kemanusiaan atau sesuai fitrah dan telah menyatu dalam dirinya (built in). Visi ini juga sebenarnya bersifat abadi dalam hati setiap orang, tidak peduli apapun perannya, apakah seorang manajer perusahaan, pejabat pemerintahan, atau seorang kepala rumah tangga.Visi ini berarti ingin menjadikan semua potensi yang ada sebagai suatu kekuatan. Baik bagi pengusaha maupun 
bukan, hal yang penting adalah memiliki visi untuk menjadikan semua potensi yang dimilikinya sebagai sebuah kekuatan. Semua potensi yang terdiri dari potensi dana, SDM, dan alam, diprogramkan atau dikelola dengan baik sehinggan menjadi sesuatu yang bermanfaat (Didin, Hendri,2003).

Visi yang baik pasti bisa diturunkan menjadi 'misi'. Misi adalah tujuan-tujuan dalam perencanaan yang mulai bersifat khusus.Meskipun visi sangat menentukan perencanaan secara keseluruhan, tetapi visi masih bersifat filosofis. Sedangkan misi sudah bersifat relatif terukur. Dengan visi seperti itu maka seharusnya dihasilkan misi islami, yaitu memberdayakan semua kekuatan sehingga menjadi sesuatu yang dapat dinikmati oleh kehidupan manusia secara luas. Di bawah ini adalah contoh uraian visi dan misi masingmasing dari suatu organisasiprofit dan non profit.

1. Organisasi :Perusahaan Swasta

Visi : Menjadi Perusahaan yang Unggul, Sejahtera dan Menyejahterakan

Misi : 1. Memuaskan konsumen

2. Menyejahterakan karyawan dan masyarakat

3. Memelihara lingkungan

4. Mempertahankan keunggulan untuk kemanfaatan yang luas

2. Organisasi : Perguruan Tinggi Islam

Visi : Pendidikan Tinggi untuk Pemberdayaan

Misi : 1. Menyadarkan masyarakat tentang pentingnya pendidikan tinggi

2. Memberikan pendidikan yang menyeluruh (komprehensif) dan bersifat islami

3. Memajukan taraf kehidupan masyarakat melalui pendidikan tinggi

\section{d. Perencanaan dan Hukum Alami Kehidupan (Sunnatullah)}

Kita memahami, bahwa keseluruhan alam dan kehidupan yang ada didalamnya adalah ciptaan Allah. Dan Allah tentu tidak menciptakan itu semua tanpa tujuan tetapi dengan tujuan atau hikmah yang jelas. Perhatikanlah firman Allah swt.dalam surat Shaad : 27.

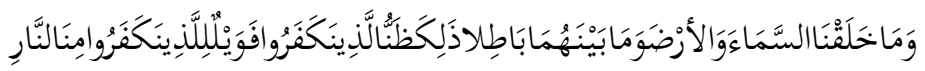

"Dan kami tidak menciptakan langit dan bumi dan apa yang ada diantara keduanya dengan sia-sia itu anggapan orang -orang kafir, maka celakalah orang - orang yang kafir itu karena mereka akan masuk. neraka." (QS. Shaad:27)

Dalam konteks keimanan kepada Kemahakuasaan Allah pasti setiap orang meyakini bahwa tidak mungkin Allah melakukan kesia-siaan seperti yang dimaksud ayat di atas. Allah tidak mungkin melakukan sesuatu hal yang tanpa tujuan dan perencanaan. Jadi, semua ciptaan-Nya yang terdapat pada alam dan kehidupan ini tidak satupun yang diciptakan tanpa perencanaan. Maka sepantasnya semua manusia dengan semua urusannya yang kompleks memiliki perencanaan dalam mencapai bermacam cita-cita kebaikan hidupnya. Dalam ayat 
yang lain tentang perencanaan yang dilakukan Allah swt atas semua hal yang terjemahannya adalah : ".........Tidak ada sesuatu pun yang Kami luputkan di dalam Al kitab, kemudian kepada Tuhan mereka dikumpulkan."(QS. Al An'am : 38)

Tentang penting dan dibutuhkannya perencanaan olehsemua pihak, konsep perencanaan syariah atau perencanaan islami menjelaskan bahwa setiap manusia (bukan hanya organisasi) harus memperhatikan apa saja yang diperbuatnya di masa lalu untuk merencanakan hal-hal yang diinginkan (baik) di masa-masa yang akan datang. Dalam syariah islam, urusan masa yang akan datang atau masa depan, terutama untuk kebahagian kehidupan di akhirat, lebih diutamakan. Allah Swt menjelaskan tentang hal ini dalam surat $\mathrm{Al}$ Hasyr ayat ke-18 :

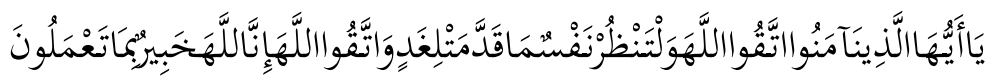

"Wahai orang - orang yang beriman! Bertakwalah kepada Allah dan hendaklah setiap diri memperhatikan apa yang telah diperbuatnya untuk. hari esok (akbirat), dan bertakwalah kepada Allah. Sungguh, Allab Mahateliti terhadap apa yang kamu kerjakan.” (QS. Al Hasyr: 18)

Konsep inti perencanaan syariah menurut ayat di atas adalah keharusan melakukan "adaptasi" dalam perencanaan. Setiap kegiatan perencanaan harus memperhatikan situasi dan kondisi yang terkait dengan masa lalu, masa kini, dan masa depan atau yang akan datang. Hal ini bisa dipahami karena 'prinsip keterkaitan' satu sama lain dari ketiga masa atau waktu itu. Karena secara umum, dalam 'siklus kehidupan' semua unsur (termasuk waktu) adalang saling terkait

Soejitno Irmin dalam buku Kepemimpinan Melalui Asmaul Husna manafsirkan atas ayat tersebut bahwa: Allah sebagai pencipta, Allah sebagai Perencana semua makhluk ciptaannya, Allah adalah Maha Merencanakan, Al-Bari, sifat tersebut jika diamalkan secara substantif seharusnya menjadi inspirasi bagi umat islam terutama para manajer atau pemimpin. Karena pada dasarnya manajer atau pemimpin yang harus mempunyai banyak konsep tentang manajemen termasuk di dalamnya perencanaan. Pemimpin yang baik adalah yang mempunyai visi dan misi, dan membangun kedua hal tersebut agar berjalan sesuai dengan tujuan bersama.Visi dan misi merupakan hasil dari perencanaan yang baik dan matang.

Al-Ghozali menafsirkan ayat tersebut sebagai berikut : bahwa manusia diperintahkan untuk memperbaiki dirinya, untuk meningkatkan keimanan dan ketakwaan kepada Allah Swt, dimana proses kehidupan manusia tidak boleh sama dengan kehidupan yang sebelumnya (kemarin). Di samping itu kata perbatikanlan menurut Iman Al-Ghazali mengandung makna bahwa manusia harus memperhatikan dari setiap perbuatan yang dia kerjakan, serta harus mempersiapkan diri (merencanakan) untuk selalu berbuat yang terbaik demi hari esok.

Imam Al-Jauhary; menafsirkan ayat tersebut sebagai salah satu bentuk dari manusia untuk selalu intropeksi diri atas segala sesuatu yang dia perbuat, perbuatan manusia harus 
difikirkan (direncanakan) agar tidak rugi dalam hidupnya sehingga beliau menafsirkan Surat Al-Hasyr Ayat 18 tersebut dengan surat At-Tinn yaitu sebagai berikut :

"Sesunggubnya Kami telah menciptakan manusia dalam bentuk yang sebaik-baiknya, kemudian Kami kembalikan dia ke tempat yang serendab-rendahnya (neraka), kecuali orang-orang yang beriman dan mengerjakan amal saleb; maka bagi mereka pabala yang tiada putus-putusnya, maka apakah yang menyebabkan kamu mendustakan (hari) pembalasan sesudah (adanya keterangan-keterangan) itu?"( Surat At-Tiin, ayat: 4-7)

Manusia harus kembali ke Tuhan-Nya dengan selamat dan sejahtera proses selamat tersebut harus dimulai dari dunia ini yang diwujudkan dengan tingkah laku yang baik, sesuai dengan apa yang tercantum dalam surat Al-Hasyr ayat 18 tersebut yaitu Kata: " hendaklah setiap diri memperbatikan apa yang telah diperbuatnya untuk hari esok (akbirat) dalam surat tersebut,"dan kata itu menekankan adanya perencanaan yang baik dalam diri manusia atas segala tindakan selama di dunia sehingga ia akan mendapatkan keselamatan di akhirat nanti.

Choiruddin Hadbiri. SP (2005), dalam bukunya "Klasifikasi Kandungan AlQur'an", menyatakan : 'Dalam setiap langkah gerak, manusia harus instrospeksi memperbatikan apa-apa yang telah diperbuatnya untuk kebaikan masa depan, dengan kata lain berarti manusia barus memiliki rencana, sebingga manusia bidupnya terarah dan tidak terjerumus ke lubang yang sama”.

Quraish Shihab dalamnya tafsir "al-Misbah", dari ayat tersebut mengenai perencanaan beliau mengatakan bahwa kata wantandur' nafsun maa koddamat li ghodinmempunyai arti bahwa manusia harus memikirkan terhadap dirinya dan merencanakan dari segala apa yang menyertai perbuatan selama hidupnya, sehingga ia akan memperoleh kenikmatan dalam kehidupan ini. Jika proses perencanaan telah dilakukan oleh Allah semenjak penciptaan manusia.

Perencanaan merupakan proses untuk menentukan ke mana harus melangkah dan mengidentifikasi berbagai persyaratan yang dibutuhkan dengan cara efektif dan efisien, sehingga perencanaan sesuai yang diinginkan dalam Surat Al-Hasyr, ayat :18, mengandung enam pokok pikiran yaitu: Pertama, perencanaan melibatkan proses penetapan keadaan masa depan yang diinginkan. Kedua, keadaan masa depan yang diinginkan dibandingkan dengan kenyataan sekarang, sehingga dapat dilihat kesenjangannya. Ketiga, untuk menutup kesenjangan perlu dilakukan usaha-usaha. Keempat, usaha untuk menutup kesenjangan tersebut dapat dilakukan dengan berbagai ikhtiar dan alternative. Kelima, perlu pemilihan alternative yang baik, dalam hal ini mencakup efektifitas dan efesiensi. Keenam, alternative yang sudah dipilih hendaknya diperinci sehingga dapat menjadi petunjuk dan pedoman dalam pengambilan keputusan maupun kebijaksanaan (www.academia.edu).

Dengan implikasi perencanaan yang benar, maka langkah awal dari sebuah tatanan proses manajemen sudah terumus dan terarah dengan baik. Perumusan dan arah yang benar merupakan bagian yang terbesar jaminan tercapainya tujuan. Dan jika yang diinginkan itu adalah sebuah kebaikan, maka kebaikan itulah yang siap untuk digenggam dan dinikmati. 
Karena pentingnya perencanaan, maka keberhasilan atau kesuksesan semua hal pasti memerlukan perencanaan, Adalah 'keberhasilan semu' bila diraih tanpa perencanaan yang baik. Seorang pebisnis misalnya, seandainya dia meraih keuntungan bisnis yang besar besar pada satu waktu, maka untuk waktu - wmtu berikutnya pasti akan mengalami banyak "kerugian" kalau dia tidak memiliki rencana bisnis ( business plan) yang baik.

Sungguh sangat jelas dan tidak bisa dipungkiri, bahwa perencanaan, terlebih lagi dalam konsep syariahislamadalah sesuatu yang penting sebelum melakukan sesuatu yang lain. Perencanaan dianggap penting karena akan menjadi penentu untuk ketercapaian tujuan. Penjelasan ini makin menguatkan alasan posisi stragetis perencanaan dalam sebuah organisasi karena dalam perencanaan dilakukan proses oleh seorang pimpinan atau manajer dalam usahanya untuk mengarahkan segala kegiatan untuk meraih tujuan.

Berdasarkan penjelasan tersebut dapat dipahami bahwa perencanaan sangat menentukan berhasil tidaknya suatu kegiatan atau program.Kegiatan yang tidak melalui perencanaan yang baik cenderung gagal.Maksudnya, suatu kegiatan sekecil dan sebesar apapun jika tanpa ada perencanaan kemungkinan besar berpeluang untuk gagal atau sebaliknya. Hal ini sesuai dengan dua adagium tentang perencanaan, "gagal dalam merencanakan berarti merencanakan kegagalan" dan "perencanaan yang baik adalah separuh pencapaian."

Dalam merencanakan sesuatu, setiap idividu atau organisasi tentu tidak mungkin tidak "dihadapkan" dengan kendala atau masalah. Masalah adalah sebentuk sunnatullah. Bahkan para Rasulullah yang hidup dalam zamanya masing - masing, juga memilki banyak masalah dalam melakukan misinya. Tetapi mereka mensikapinya secara positif, yaitu dengan cara memahami bahwa masalah adalah peluang untuk meningkatkan kemampuan mereka dalam melakukan misinya. Mereka sangat meyakini keberhasilan - keberhasilan yang akan terjadi dengan semua pertolongan Allah swt. usaha - usaha wajar manusiawi yang dilakukannya.Satu diantaranya adalah motivasi dari Allah swt dalam Al Qur'an (terjemahan) surat al-Insyirah : 5-6, yaitu : "Karena sesunggubnya sesudah kesulitan itu ada kemudahan. Sesunggubnya sesudah kesulitan itu ada kemudaban."

Didin hafidhuddin dan Hendri Tanjung (2003) mengemukakan tentang hal tersebut dalam buku mereka yang berjudul Manajemen Syariah dalam Praktik, pada umumnya, seseorang selalu menginginkan berbagai kemudahan.Padahal dilain sisi, kemudahan kemudahan tersebut tidak aka nada kecuali setelah melalui berbagai kesulitan. Kesuksesan seseorang yang sesunguhnya adalah kesuksesan ketika ia dapat mengatasi masalah. Seseorang yang berhasil, katakanlah seorang manajer yang berhasil, pada hakikatnya pada hakikatnya belum dapat dikatakan berhasil jika ia tidak pernah mendapatkan masalah.“..... Ketahuilah bahwa bersama kesabaran, bersama kesusahan ada jalan keluar, bersama kesulitan ada 
kemudahan.” (HR Tirmidzi)Masih menurut keduanya, mengatasi masalah juga harus dengan perencanaan.Jika seorang manajer mendapat masalah mengenai pegawai yang belum nberkualitas atau kualitasnya belum memenuhi harapan, maka hal itu harus diatasi. Perencanaan yang disusun pun harus perencanaan yang matang. Untuk mengatasi masalah ini, suatu perusahaan dapat menugaskan salah satu pegawainya untuk pendidikan singkat (short course), baik yang diploma dan sebagainya. ${ }^{\mathrm{i}}$

\section{e. Kelayakan (Visibility) dalam Perencanaan}

Jika Individu atau suatu organisasi menginginkan perencanaan yang baik, maka sangat diperlukan kelayakan (visibility). Didin dan Hendri Tanjung (2003) berpendapat bahwa kelayakan pada dasarnya terbagi menjadi dua hal. Pertama, dilihat berdasarkan orang yang melakukannya atau mengerjakannya. Kedua, berdasarkan sesuatu yang dikerjakan. Jika merencanakan sebuah kegiatan usaha, maka perlu diteliti apakah kegiatan usaha itu layak didirikan di suatu tempat yang dipilih? Menguntungkan atau tidak ?Apakah menguntungkan bagi masyarakat disekitarnya? Demikian juga dalam hal kesiapan melakukan suatu pekerjaan. ii Misalnya, kalau Giant ingin membuka outlet baru di suatu wilayah perkotaan, maka perlu direncanakan dengan baik apakah para pekerjanya cukup mengandalkan orang - orangdi sekitar wilayah dimaksud, atau merekrut dari luar wilayah tersebut. Demikian juga misalnya, kalau Giant tersebut akan menjual produk-produk minuman yang terlarang (haram) dikonsumsi oleh masyarakarakat muslim, khususnya di wilayah tersebut. Hal ini tentunya tidak layak untuk dilakukan.

Disamping hal-hal yang bersifat riil (mikro), hal-hal yang bersifat makro juga harus diperhatikan dalam suatu perencanaan. Misalnya sisi politik, sosial, dsan ekonomi masyarakat.Secara umum, kehidupan masyarakat sangat dipengaruhi oleh itu semua, meskipun hal-hal tersebut bukan satu-satunya yang menentukan.

\section{f. Tahapan Perencanaan}

Suatu perencanaan yang baik harus memiliki tahapan yang baik juga.Secara umum, untuk perencanaan apapun memiliki empat tahapan. Pertama, analisis kebutuhan dan kemampuan. Secara fisik dan mental perlu dipahami apakah misalnya perlukah membuka suatu usaha rumah makan di daerah tertentu. Kedua, analisis kekuatan dan kelemahan (analisis SWOT). Ketiga, menyusun program dan langkah kerja. Hasil kedua macam analisis tersebut bisa dijadikan dasar yang kuat seorang manajer atau pejabat suatu instansi pemerintah misalnya dalam menyusun langkah kerja. Keempat, evaluasi (penilaian). Bukanlah suatu perencanaan yang baik kalau tanpa evaluasi perlu dan harus dilakukan di awal, di tengah, dan di akhir perencanaan. Jadi, evaluasi dilakukan pada setiap tahap perencanaan seperti yang telah dijelaskan di atas. Evaluasi yang dilakukan dengan baik akan menghasilkan penyusunan program-program dan kegiatan-kegiatanyang baik. 


\section{KESIMPULAN}

Perencanaan syariah sesungguhnya adalah perencanaan pada umumnya yang terpadu dengan nilai-nilai kebaikan syariah islam. Inilah perencanaan yang dapat dipertanggungjawabkan (akuntabel) tidak saja di dunia tetapi juga di akhirat nanti. Perencanaan syariah bukanlah sekedar perencanaan yang ditambahkan dengan dalil-dalil syariah, karena bila dipahami demikian, ini adalah kesalahan yang mungkin cukup fatal. Suatu perencanaan mengandung banyak kebaikan ibadah kepada Allah SWT, dan ini hanya terdapat pada perencanaan yang tolak ukurnya adalah tujuan-tujuan baik yang bersesuaian dengan nilai-nilai islam. Supaya perencanaan syariah dapat dipahami dengan baik oleh orang banyak, terutama masyarakat islam, maka perlu adanya sosialisasi. Setiap muslim dengan perannya masing-masing, hendaknya memahami, meyakini, dan mengamalkan konsep perencanaan syariah. Dengan demikian, ia tidak merasa "asing" dengan suatu bagian dari ajaran agamannya sendiri, yaitu al islam. Kondisi ini harus dihindari, supaya tidak terjadi "kerugian-kerugian” yang menyesalkan.

\section{REFERENSI}

Buqha Musthafa Al dan Muhyiddin Misto. 2002. Pokok-Pokok Ajaran Islam. Robbani Press, Cetakan pertama, Jakarta

Hadhiri , Choiruddin SP. 2005. Klasifikasi Kandungan Al Qur'an Jilid I. Gema Insani Press, Cetakan pertama, Jakarta

Hafidhuddin, Didin dan Hendri Tanjung. 2003. Manajemen Syariah Dalam Praktik. Gema Insani Press, Cetakan pertama, Jakarta

Hidayat, R. Ahmad. 2013. The Holy Qur'an Al Fatih. Al Fatih, Cetakan kelima, Jakarta

Robbins Stephen P. dan Mary Coulter. 1999. Manajemen Jilid I, Prenhallindo, Edisi keenam, Jakarta

www.slideshare.net2014 